Institute of $\mathbf{F}_{\text {ood and }} \mathbf{A}_{\text {gricultural }} \mathbf{S}_{\text {ciences }}$

\title{
2003 Handbook of Employment Regulations Affecting Florida Farm Employers and Workers: Family and Medical Leave Act of 1993 [Federal] ${ }^{1}$
}

Leo C. Polopolus, Michael T. Olexa, Fritz Roka, and Carol Fountain ${ }^{2}$

\section{Purpose}

To provide for unpaid job protected leave for family and medical reasons.

\section{Employer Coverage}

The Family and Medical Leave Act (FMLA) of 1993 defines covered employers as those who are engaged in or affect interstate commerce if they employ fifty or more workers during twenty or more weeks in the current or preceding year. Most agricultural businesses fall under the interstate commerce definition.

Employers using the services of farm labor contractors (FLCs) may find that their permanent and seasonal workers, added to the FLC's crew, equal the fifty or more workers over a twenty-week period.

FMLA's definition of joint employment is similar to that of the Fair Labor Standards Act, which in agriculture usually presumes a joint employment status.

\section{Employee Coverage}

To be covered by the FMLA, an employee must meet all the following criteria:

- Have worked for the employer at least twelve months (not necessarily consecutive months; working any part of a week counts as a whole week).

1. This is EDIS document FE396, a publication of the Department of Food and Resource Economics, Florida Cooperative Extension Service, Institute of Food and Agricultural Sciences, University of Florida, Gainesville, FL. Published July 2003. This information is included in Circular 1200, Handbook of Employment Regulations Affecting Florida Farm Employers and Workers. First published February 1992 as Circular 1043 . Revised December 2002 as Circular 1200. Please visit the EDIS website at http://edis.ifas.ufl.edu.

2. Leo C. Polopolus, Professor Emeritus, Department of Food and Resource Economics, University of Florida, Gainesville, FL; Michael T. Olexa, Professor, Department of Food and Resource Economics, University of Florida, Gainesville, FL; Fritz Roka, Associate Professor, Department of Food and Resource Economics, Southwest Florida Research and Education Center, Immokalee, FL; and Carol Fountain, Assistant Editor, Department of Food and Resource Economics, University of Florida, Gainesville, FL; Florida Cooperative Extension Service, Institute of Food and Agricultural Sciences, University of Florida, Gainesville, FL.

This document is designed to provide accurate, current, and authoritative information on the subject. However, since the laws, administrative rulings, and court decisions on which it is based are subject to constant revision, portions of this publication could become outdated at any time. This publication is distributed with the understanding that the authors are not engaged in rendering legal or other professional advice, and the information contained herein should not be regarded as a substitute for professional advice. For these reasons, the utilization of these materials by any person constitutes an agreement to hold harmless the authors, the Institute of Food and Agricultural Sciences, and the University of Florida for any liability claims, damages, or expenses that may be incurred by any person as a result of reference to or reliance on the information contained in this publication.

The Institute of Food and Agricultural Sciences is an equal opportunity/affirmative action employer authorized to provide research, educational information and other services only to individuals and institutions that function without regard to race, color, sex, age, handicap, or national origin. For information on obtaining other extension publications, contact your county Cooperative Extension Service office. Florida Cooperative Extension Service/Institute of Food and Agricultural Sciences/University of Florida/Christine Taylor Waddill, Dean. 
- Have worked at least 1,250 hours over the previous twelve-month period preceding leave.

- Work at a work site, or within seventy-five miles of a work site, where at least fifty workers are employed by the employer.

Under FMLA, work sites are single locations or a group of sites within the seventy-five mile area.

\section{Basic Provisions}

Employers covered by FMLA are required to permit eligible employees to take up to twelve weeks of unpaid leave during a twelve-month period for any of the following reasons:

- For the birth of a child, or placement of a child for adoption or foster care.

- To care for a spouse, child, or parent with a serious health condition.

- For employee's own serious health condition that makes the person unable to perform job.

A serious health condition involves inpatient care in a medical facility or continuing treatment by a health care provider. FMLA was not designed to cover short-term illnesses like colds or flu.

FMLA requires the employer to protect the employee's job, benefits, and seniority during the FMLA leave period. The employee must be restored to his or her previous position, or an equivalent position, with equal pay, benefits, and other terms and conditions of the job.

Group health insurance coverage must be maintained unchanged for the duration of the leave, even if a co-payment arrangement is customary. In this situation, an employer must make arrangements for the employee on FMLA leave to continue to pay the appropriate share of health insurance premiums during the leave period.

Other benefits such as sick leave or vacation time may, but are not required to, accrue during the FMLA leave period. Be sure not to dock leave earned before the commencement of FMLA leave.
Employers may require employees to exhaust accrued vacation, sick leave, or personal leave before taking FMLA leave.

When the leave is for the birth or adoption of a child, the FMLA requires the employee to give thirty-days' notice of his or her intent to take leave. However, if the date of the birth or adoption requires leave to begin in less than thirty days, the employee must give such notice as is practicable.

Notification requirements are similar for leaves due to a serious health condition. The FMLA enables employers to require medical certification to support a request for leave because of a serious health condition. The employer may also require second or third medical opinions, at the employer's expense.

\section{Determining the Twelve-Month Period}

The employer is permitted to choose any one of the following methods for determining the twelve-month period in which the twelve weeks of leave entitlement occurs:

- The calendar year.

- Any fixed twelve-month leave year, such as a fiscal year, a year required by state law, or a year starting on an employee's anniversary date.

- The twelve-month period measured forward from the date of any employee's first FMLA leave begins.

- A rolling twelve-month period measured backward from the date an employee uses any FMLA leave.

\section{On Return from FMLA Leave}

An employee is entitled to be returned to the same position the employee held when leave commenced or to an equivalent position with equivalent benefits, pay, and any other terms and conditions of employment. An employee is entitled to such reinstatement even if the employee has been replaced or his or her position has been restructured to accommodate the employee's absence. If the employee is unable to perform an essential function 
of the position because of a physical or mental condition, including the continuation of a serious health condition, the employee has no right to restoration to another position under the FMLA. However, the employer's obligations may be governed by the Americans with Disabilities Act (ADA). An equivalent position is one that is virtually identical to the employee's former position in terms of pay; benefits; and working conditions, including privileges, perquisites, and status. It must involve the same or substantially similar duties and responsibilities, which must entail substantially equivalent skill, effort, responsibility and authority. An employer may deny job restoration to salaried eligible employees (key employees), if such denial is necessary to prevent substantial and grievous economic injury to the operations of the employer or may delay restoration to an employee who fails to provide a fitness-for-duty certificate to return to work. Under the Act, a key employee is a salaried FMLA-eligible employee who is among the highest paid ten percent of all the employees employed by the employer within seventy-five miles of the employee's worksite.

\section{Posting Requirement}

Every employer covered by the FMLA is required to post and keep posted on its premises, in a conspicuous place where employees are employed, whether or not it has any eligible employees, a notice explaining the Act's provisions and providing information concerning the procedures for filing complaints of violations of the Act with the Wage and Hour Division. The notice must be posted prominently where it readily can be seen by employees and applicants for employment. In addition, if an FMLA-covered employer has any eligible employees and has any written guidance to employees concerning employee benefits or leave rights (e.g., employee handbook), information concerning FMLA entitlements and employee obligations under the FMLA must be included in the handbook or other documents. If such employer does not have written policies, manuals, or handbooks describing employee benefits and leave provision, the employer must provide written guidance to any employee concerning all the employee's rights and obligations under the FMLA. This notice must be provided to employees each time notice is given.

\section{When Leave Is Not Foreseeable}

When the approximate timing of the need for leave is unforeseeable, an employee should give notice to the employer of the need for FMLA leave as soon as practicable under the facts and circumstances of the particular case. It is expected that an employee will give notice to the employer within no more than one or two working days of learning of the need for leave, except in extraordinary circumstances where such notice is unfeasible. In the case of a medical emergency requiring leave because of an employee's own serious health condition or to care for a family member with a serious health condition, written advance notice pursuant to an employer's internal rules and procedures may not be required when FMLA leave is involved. If an employee fails to give timely advance notice when the need for FMLA leave is foreseeable, the employer may delay the taking of FMLA leave until thirty days after the date the employee provides notice to the employer of the need for FMLA leave. If an employee fails to provide in a timely manner a requested medical certification to substantiate the need for FMLA leave due to a serious health condition, an employer may delay continuation of FMLA leave until an employee submits the certificate.

\section{FMLA and Antidiscrimination Policy}

Nothing in FMLA modifies or affects any Federal or State law prohibiting discrimination on the basis of race, religion, color, national origin, sex, age, or disability (e.g., Title VII of the Civil Rights Act of 1964, as amended by the Pregnancy Discrimination Act). FMLA's legislative history explains that FMLA is not intended to modify or affect the Rehabilitation Act of 1973, as amended; the regulations concerning employment which have been promulgated pursuant to that statute; or the Americans with Disabilities Act of 1990 or the regulations issued under that Act. 


\section{FMLA and ADA}

If an employee is a qualified individual with a disability within the meaning of the Americans with Disabilities Act (ADA), the employer must make reasonable accommodations, barring undue hardship, in accordance with the ADA. At the same time, the employer must afford an employee his or her FMLA rights. ADA's disability and FMLA's serious health condition are different concepts and must be analyzed separately. FMLA entitles eligible employees to twelve weeks of leave in any twelve-month period. Whereas the ADA allows an indeterminate amount of leave, barring undue hardship, as a reasonable accommodation. FMLA requires employers to maintain an employee's group health plan coverage during FMLA leave on the same conditions as coverage would have been provided if the employee had been continuously employed during the leave period. Whereas ADA does not require maintenance of health insurance unless other employees receive health insurance during leave under the same circumstances.

\section{Enforcement}

Failure to post an FMLA poster in a conspicuous place can result in a civil money penalty of up to $\$ 100$ for each separate offense.

Eligible employees denied leave or reinstatement may file a complaint with the U.S. Department of Labor. They are also entitled to file a private right of action lawsuit to obtain relief.

The FMLA provides damages equal to lost wages, benefits, and other compensation. Employees may also receive compensation for actual losses, such as the cost of care for children or parents, up to an amount equal to twelve weeks (of the employee's) earnings. Courts may also award employees attorneys' fees and related costs.

\section{Additional Information}

- USDL Issues Final Family and Medical Leave Act (FMLA) Regulations. FFVA Labor Bulletin, No. 502, February 17, 1995 (Report from USDL).

\section{Responsible Agency}

Regional Office

U.S. Department of Labor

ESA Wage and Hour Regional Office

61 Forsyth Street, Room 6M12

Atlanta, GA 30303

(404) 562-2092

http://www.doleta.gov/regions/reg03

\section{District Offices}

District Director

3728 Phillips Highway, Suite 219

Jacksonville, FL 32207 (904) 232-2489

District Director

10300 Sunset Drive, Room 255

Miami, FL 33173-3038

(305) 598-6607 [English] (

305) 598-7471 [Spanish/Creole]

District Director

4905 West Laurel Avenue, Suite 300

Tampa, FL 33607-3838

(813) 288-1242 